\title{
İstanbul'da Yaşayan Geçici Koruma Statüsündeki Suriyelilerin Türk Vatandaşlığına İlişkin Görüşleri
}

The Views of Syrians Living in Istanbul Who Have the Temporary Protection Status on Turkish Citizenship

\section{Mehmet Tayfun Amman* - Esma Altındiş̧*}

\section{Öz}

2011 yılında Suriye'de başlayan iç savaş sonrası günümüz dünyasının en büyük insani krizlerinden biri yaşanmıştır. Bu krizden sadece Suriye halkı etkilenmemiş, sınır komşusu olan Türkiye'de kitlesel göç akımıyla savaştan en çok etkilenen ülke olmuştur. Bu insani kriz sonucunda Türkiye "açık kap1 politikası" ilan ederek Suriye halkına ülke sınırlarını açmıştır. Resmi kaynaklardan alınan verilere göre 2019 yılı itibari ile Türkiye'de 3,5 milyonu aşkın Suriyeli bulunmaktadır. Yaklaşık 8 yıldır süren iç savaşın bitmemesi bu sayının giderek artmasına ve gelen göçmenlerin geri dönme ümidini azaltarak onları topluma entegre olmaya ve vatandaşlık istemeye teşvik etmektedir. Yapılan bu çalışmada geçici koruma statüsündeki Suriyelilerin vatandaşlık alma duruma dair düşünceleri; misafirlik, geçicilik/kalıcılık ve vatandaşlık kavramları çerçevesinde analiz edilmiştir. Bu çalışma, nitel bir araştırma modeli oluşturularak geçici koruma kapsamındaki 30 Suriyeli ile yapılan mülakatlar sonucunda gerçekleştirilmiştir.

Anahtar Kavramlar: Göç, Geçici Koruma, Suriyeliler, Türk Vatandaşlı̆̆ı

" Prof. Dr., Sakarya Üniversitesi, Fen-Edebiyat Fakültesi, Sosyoloji Bölümü Öğretim Üyesi, mtamman@sakarya.edu.tr

" YLS öğrencisi, Sakarya Üniversitesi Sosyal Bilimler Enstitüsü Sosyoloji Anabilim Dalı, esma.altindis@gmail.com

Bu makale iThenticate sistemi tarafından taranmıştır.

Makale Gönderim Tarihi: 22 Mart 2019 


\begin{abstract}
After the civil war started in Syria in 2011, one of the biggest humanitarian crises in today's world has been experienced. This crisis not only affected the people of Syria. Being a bordering country Turkey has been the most affected by the war of massive migration. As a result of this humanitarian crisis, Turkey has opened its borders to the Syrian people by declaring the "open door policy". According to 2019 data received from official sources, there are over 3.5 million Syrians in Turkey. The fact that the civil war that has been going on for about 8 years has not ended is increasing this number and decreasing the hope of arriving migrants by encouraging them to integrate into the society and want citizenship. In this study, the opinions of Syrians with temporary protection status regarding citizenship status were analyzed within the framework of the concepts of hospitality, temporality / permanence, and citizenship. By establishing a qualitative research model, this study was conducted as a result of interviews with 30 Syrians in the context of temporary protection.
\end{abstract}

Keywords: Migration, Temporary Protection, Syrians, Turkish Citizenship 


\section{Giriş}

Suriye' de 2011 yılında başlayan iç savaş ile birlikte Türkiye'ye kitlesel göç akımı başlamıştır. Yaşanan çatışmalar ve bombardımanlar sonucu Suriye vatandaşları çareyi ülke dışına çıkmakta bulmuştur. Bu insani dram karşısında Türkiye açık kapı politikası uygulamış ve zamanla 3,5 milyonu aşkın Suriyeli Türkiye'ye sığınmıştır. Suriyelilerin hukuki ve toplumsal anlamda Türkiye'deki konumu uzun süre ülke gündemini meşgul etmiştir. Gerek görsel ve yazılı medyada gerekse siyasi alanda Suriyeliler için misafir, sığınmacı ve mülteci tanımları yapılırken zamanla bir kavram kargaşası meydana gelmiştir. Tarihsel anlamda bu konuyu hukuki bir zemine oturtmak gerekmektedir. Uluslararası alanda ilk yasal zemin 1951 yılında pek çok devlet tarafından imzalanan "Mültecilerin Hukuki Statüsüne İlişkin Cenevre Sözleşmesi” ve daha sonra buna ek olarak düzenlenen "1967 Protokolü" olarak kayitlara geçmiştir. Ülkemizde ise 1961 yılında Resmi Gazete' de yayınlanan Mültecilerin Hukuki Statüsüne İlişkin Sözleşme' de; “....rkı, dini, tabiiyeti, belli bir toplumsal gruba mensubiyeti veya siyasi düşünceleri yüzünden, zulme uğrayacağından haklı sebeplerle korktuğu için vatandaşı olduğu ülkenin dışında bulunan ve bu ülkenin korumasından yararlanamayan, ya da söz konusu korku nedeniyle yararlanmak istemeyen yahut tabiiyeti yoksa ve bu tür olaylar sonucu önceden yaşadığı ikamet ilkesinin dışında bulunan, oraya dönemeyen veya söz konusu korku nedeniyle dönmek istemeyen..." her şahsın mülteci olarak kabul edileceği ifade edilmiştir (Mültecilerin Hukuki Durumuna İlişkin Sözleşme, 2015:2).

Türkiye bu sözleşmeleri kabul edip imza atmasına rağmen birkaç sınırlama ile bazı şartlar koymuştur. Bunlardan bir tanesi "coğrafi sınırlama" şartıdır. Bu sınırlama ile hangi sebeple olursa olsun Avrupa dışından gelen yabancı kişiler Türkiye'de mülteci olarak nitelendirilmemektedirler. Bu sebeple Suriye vatandaşları hukuki anlamda mülteci olarak kabul edilmemektedir. Yine sığınmacı da mültecilik talebinde bulunan kişilere verilen bir isimdir. Suriyelilerin mülteci olarak kabul edilmemesi onları sığınmacı olarak tarif etmeyi de zorlaştırmaktadır. Kavram tartışmalarının nihayetinde devlet, Suriyelilerin hukuki statüsünü belirlemeye 
yönelik yeni bir yönetmelik yayınlamıştır. Resmi Gazete' de 22 Ekim 2014 tarihinde yayınlanan "Geçici Koruma Yönetmeliği" ile ülkesinden ayrılmaya zorlanmış, ayrıldığı ülkesine dönemeyen, kitlesel ve acil olarak sınırlarımıza gelen kişilerin Geçici Koruma Kapsamı'na alınacağı belirtilmiştir. Böylelikle devlet, Suriyelilere hukuki anlamda "Geçici Koruma Statüsü" vermiştir. Ekim 2014'te Resmi Gazete' de yayınlanan Geçici Koruma Yönetmeliği'nde şu ifadeler kullanılmıştır:

“Geçici koruma; ülkesinden ayrılmaya zorlanmış, ayrıldığı ülkeye geri dönemeyen, acil ve geçici koruma bulmak amacıyla kitlesel veya bu kitlesel akın döneminde bireysel olarak sınırlarımıza gelen veya sınırlarımızı geçen yabanclardan haklarında bireysel olarak uluslararası koruma statüsü belirleme işlemi yapılamayan yabancılara uygulanır." (Geçici Koruma Yönetmeliği, 2017). Suriyelilere "Geçici Koruma Kapsamı" altında belirli bir süre için Türkiye'de kalma izni verilmiştir. Geçici Koruma Yönetmeliği'nce Suriyelilere geçici koruma kimlik belgesi verilmesine karar verilmiştir. Böylece Suriyelilerin sağlık, eğitim, istihdam, sosyal destek ve tercümanlık hizmetlerinden faydalanabilmesi sağlanmaktadır. Geçici koruma kimliğine sahip olan Suriyeliler için çalışma izni de verilmektedir (Kap, 2014:329).

Suriye' deki savaşın hala devam etmesi ve Suriyelilerin geçici olarak koruma kapsamına alınması gelecekleri hakkında belirsizliğin büyümesine neden olmaktadır. Önceleri misafir olarak kabul edilen Suriyeliler, sürecin uzaması ile birlikte ülkelerine olan aidiyetini kaybetme ve yeni bir vatan edinme durumuyla karşı karşıya kalmaktadır. Bu nedenle vatandaşlık isteme noktasında nasıl bir düşünceye sahip oldukları Suriyelilerin Türkiye'ye uyum ve entegrasyonu hakkında bilgi edinebilmek açısından önemli bir yere sahiptir.

\section{Göç, Vatandaşlık Ve Suriyeliler}

Göç, nedenleri, dinamikleri ve sonuçlarıyla en büyük insani hareketliliklerden biridir. Bundan dolayı göç hakkında net bir tanım yapabilmek güçtür. Yine de kapsamı bakımından göçü şöyle tanımlayabiliriz; "ekonomik, siyasi, ekolojik veya bireysel neden- 
lerle, bir yerden başka bir yere yapılan ve kısa, orta veya uzun vadeli geriye dönüş veya sürekli yerleşim hedefi güden coğrafik, toplumsal ve kültürel bir yer değiştirme hareketidir." (Yalçın, 2004:13). Göç Terimleri Sözlüğü'nde ise göç olgusu; “Uluslararası bir sınırı geçerek veya bir devlet içinde yer değiştirmek. Süresi, yapısı ve nedeni ne olursa olsun insanların yer değiştirdiği nüfus hareketleridir. Buna mülteciler, yerinden edilmiş kişiler, yerinden çıkarılmış kişiler ve ekonomik göçmenler dâhildir." şeklinde açıklanmıştır (Uluslararası Göç Örgütü, 2009:22). Daha iyi bir yaşam sürme isteği ile gönüllü olarak göç eden kişiler olduğu gibi yaşadığı zulümden kurtulmak için ya da iç savaş ve doğal afet gibi nedenlerden dolayı zorunlu olarak bulunduğu yerden ayrılmak zorunda kalan göçmenlerde bulunmaktadır.

Göç edildikten sonraki süreç, hem göç eden kişiler hem de yerel toplum açısından bir takım zorluklar ve sıkıntıları da beraberinde getirmektedir. Bu problemlerin aşılması noktasında gelen kişilerin topluma uyum sağlaması ve ev sahibi toplumun gelen göçmenleri kabul etmesi önemli bir aşama olarak görülmektedir. Buna ek olarak göçmenlerin geldikleri ülkede hak talep edebilmek ve haklarını güvence altına alabilmek için vatandaşlık alma noktasındaki istekleri de toplumdaki yerini belirlemeye yönelik bir istektir. Fakat vatandaşlık almak bir dizi şartların yerine getirilmesi ile mümkündür. Ülkeye gelen yabancıların hangi sebeple ve nasıl ülkeye girip yerleştiğinden, neden vatandaşlık almak istediğine dair pek çok farklı faktör işin içine girmektedir.

Vatandaşlık tanımıyla birtakım haklar ve görevler ifade edilmektedir. Birey ile devlet arasındaki ilişki vatandaşlık statüsü ile temsil edilmektedir. Vatandaşlık yasal bir statüyü ifade ettiği gibi kişiye verilen bir kimlik olarak görülmektedir (Güney \& Konak, 2016:119). Kimi durumda bir göç hareketinin sonucu olarak da kabul edilebilen vatandaşlık; siyasi, ekonomik, hukuki ve sosyolojik boyutları olan bir kavramdır. Turner, vatandaşlığın sosyolojik yönünü vurgulayarak vatandaşlığı: "bir kişiyi toplumun yetkin bir parçası olarak tanımlayan ve bunun sonucunda kaynakların kişilere ve sosyal gruplara akışını şekillendiren bir dizi (hukuki, siyasi, ekonomik, kültürel) uygulama" olarak tanımlamıştır (Turner, 
1993:2' den akt. TBMM Araştırma Merkezi, 2011:1). T. H. Marshall ise vatandaşlığı bir topluluğa aidiyet hissetme durumu ile ilişkilendirmiştir (TBMM Araştırma Merkezi, 2011:1).

Ülkemizde ise 1982 Anayasasının 66. Maddesinde Türk vatandaşlığına ilişkin şu ibareler yer almaktadır: “Türk Devleti'ne vatandaşlık bağı ile bağlı olan herkes Türk'tür. Türk babanın veya Türk ananın çocuğu Türk'tür. Vatandaşlık, kanunun gösterdiği şartlarla kazanılır ve ancak kanunda belirtilen hallerde kaybedilir" (Türkiye Cumhuriyeti Anayasası). Yine anayasada "Her Türk vatandaşının bu Anayasadaki temel hak ve hürriyetlerden eşitlik ve sosyal adalet gereklerince yararlanarak millî kültür, medeniyet ve hukuk düzeni içinde onurlu bir hayat sürdürme ve maddî ve manevî varlığını bu yönde geliştirme hak ve yetkisine doğuştan sahip olduğ u" belirtilmiştir (Türkiye Cumhuriyeti Anayasası). Türk vatandaşı olmak birtakım şartlar altında sonradan gerçekleşebilirse de kan bağı ve toprak esası şartının aynı anda sağlanması gerekmektedir. Buna göre anne ya da babanın Türk olmasına ek bir de Türkiye topraklarında doğmuş olma şartı söz konusudur. Bu nedenle Suriyelilerin Türkiye'de doğan çocukları vatandaşlığa alınmamaktadır. Ayrıca Türk vatandaşlığına başvuru yapabilmek için 5 yılı aşkın sürede Türkiye'de ikamet etmiş olma şartı da bulunmaktadır (Gülyaşar, 2017:684). Geçici Koruma Yönetmeliği'nde ise geçici koruma kimlik belgesi verilen kişilere ikamet izni verilmediği bununla birlikte uzun süreli ikamet iznine geçiş hakkının da verilmediği ayrıca belirtilmiş ve bundan dolay1 geçici koruma kimlik belgesinin sahibine Türk vatandaşlığına başvuru hakkı sağlamayacağı ifade edilmiştir (Geçici Koruma Yönetmeliği, 2017). Bu bağlamda geçici koruma statüsünde olan Suriyelilerin şu anki yasal durumda vatandaşlık alabilmesi mümkün görünmemektedir. Fakat Suriyeliler özelinde yeni bir yönetmelik yayınlanırsa diğer yabancılara vatandaşlık hakkı sağlandığı gibi geçici koruma statüsü kaldırılarak Suriyelilere de vatandaşlık verilebilir.

Gündeme bakıldığında ise Suriye' den gelen kişilerin vatandaşlık aldığına dair medyada birtakım haberler yer almaktadır. İçişleri Bakanı Süleyman Soylu 2019'un Ocak ayında verdiği bir röportaj- 
İstanbul'da Yaşayan Geçici Koruma Statüsündeki

Suriyelilerin Türk Vatandaşlığına İlişkin Görüşleri

da "şimdiye kadar kaç Suriyeliye vatandaşlık verildi?" sorusuna şu cevabı vermiştir:

“Toplam 76 bin 443, bunlarm 36 bini reşit. 5 bin 292 öğretmen, 1432 mühendis, 1235 serbest meslek sahibi, 743 doktor, 732 teknisyen, 507 küçük işyeri sahibi, 427 müdür, 396 tüccar, 392 muhasebeci, avukat, eczacl, üst düzey yönetici, hemşire, mimar, çevirmen, bankacı, akademisyen; bütün bunlar var." (www.habertürk.com, 2019).

Tüm bu rakamlarda bahsedilen kişilerin statülerinin öne çıkarılması bu anlamda nitelikli olma şartını akıllara getirmektedir. Zira Suriyelileri vatandaşlığa alma noktasında farklı ölçütlerin göz önünde bulundurulacağı gerek siyasiler arasında gerekse de yazılı ve görsel medyada çoğu kez vurgulanmaktadır. İyi bir güvenlik soruşturması, Türkiye'de geçirdiği süre ve diğer şartların sağlanması durumunda ve geçici koruma statüsünün kaldırılıp yeni bir düzenlemeye gidildiğinde Suriyelilerin Türk vatandaşlı̆̆ı alması gerçekleşebilir.

Suriyelilerin şu anki durumları düşünüldügüünde ülkelerinde bitmeyen savaş, geçen yıllar ve özellikle ikinci kuşak çocukların Türkiye'ye daha fazla uyum sağlayarak aidiyet kazanmaları gibi pek çok farklı etken onları vatandaşlık elde etme mücadelesine itmektedir. Suriyelilerin Türk vatandaşlığı alma durumuna dair düşüncelerinin analiz edilmesi onların toplumdaki yerini belirleme, uyum sağlama ve gelecek beklentileri hakkında detaylı bilgiler edinme açısından önemlidir.

\section{Araştırmanın Yöntemi}

Araştırma süreci için nitel araştırma modeli seçilmiştir. Burada uygulanan yöntem, araştırmaya katılan bireylerin düşüncelerini ve görüşlerini ortaya çıkararak derinlemesine bilgiler ve veriler elde etmeye yöneliktir. Nitel veri toplama tekniklerinden olan "mülakat" araştırma için en uygun veri toplama tekniği olarak belirlenmiştir. Araştırmanın yarı-yapılandırılmış mülakat formu ile gerçekleştirilmesi uygun görülmüştür. Yarı-yapılandırılmış mülakat formu, görüşmenin seyrine göre yeni sorularla konunun derinine inilmesine ve bilgilerin çeşitlenmesine imkân vermektedir. 
Çalışma kapsamında, 2019 yılı Şubat ayında İstanbul'da ikamet eden farklı sosyo-demografik özelliklere sahip 30 Suriyeli ile görüşmeler gerçekleştirilmiştir. Katılımcılara Suriyeli bir dernekten alınan bilgiler ışığında kota örnekleme tekniği ve görüşülen kişilerin bir başka kişiye yönlendirmesi sonucu ulaşılan kartopu örneklem tekniği uygulanmıştır. Ayrıca katılımcılardan Türkçe bilen ve bilmeyen olmak üzere eğitim, yaş, cinsiyet, medeni durum, meslek, Türkiye'de kaldıkları süre ve geldikleri şehir bakımından farklılık göstermesi dikkate alınarak sosyo-demografik çeşitlilik sağlanmaya çalışılmıştır. Görüşülen kişilerin 12'si erkek 18'i kadındır. Görüşülen kişilerin eğitim durumları şu şekildedir; 1 kişi okuma-yazma bilmemekle beraber 6 kişi ilkokul, 13 kişi ortaokul, 9 kişi lise ve 1 kişide üniversite mezunudur. Görülen kişilerin 24'ü evli, 4'ü bekâr, 2'si de duldur. Suriyelilerin geldikleri şehirlere göre dağılımı şu şekildedir; 20 kişi Halep, 5 kişi Şam, 2 kişi İdlip, 1 kişi Humus, 1 kişi Deraa ve 1 kişi Deyr Ez Zor şehrinden Türkiye'ye gelmiştir. Ortalama 10 dakikalık görüşmeler gerçekleştirilmiştir. Türkçe bilmeyen katılımcılarla tercüman aracılığıyla iletişim kurulmuştur. Görüşmeler yazı haline getirilerek çeşitli veriler elde edilmiştir. Bu veriler betimsel ve içerik olarak analiz edilmiştir. Analiz sürecinin ilk aşamasında görüşme formundaki soruların odak noktası olarak misafirlik, geçicilik/kalıcılık, vatandaşlık temaları öne çıkarak bu doğrultuda veriler düzenlenmiştir. Bir sonraki aşamada araştırmanın verileri sosyo-demografik özelliklerin betimlenmesi, misafirlik algısının ortaya koyulması, gelecek beklentisinin geçicilik/kalıcılık üzerinden betimlenmesi ve vatandaşlık alma eğilimlerinin betimlenmesi şeklinde sınıflandırılmıştır. Ardından elde edilen veriler tanımlanmış ve doğrudan alıntılarla desteklenmiştir. İçerik analizi ile vatandaşlık alma nedeni doğrultusunda verilerin içerisinde saklı olan ve tekrar eden kavramlara ulaşılmıştır. Elde edilen bulguların anlamlandırılması ve ilişkilendirilmesi için gerekli yerlerde yorumlama tekniği kullanılmıştır. 
İstanbul'da Yaşayan Geçici Koruma Statüsündeki Suriyelilerin Türk Vatandaşlığına İlişkin Görüşleri

Tablo 1: Görüşülen Suriyelilerin Sosyo-Demografik Özellikleri

\begin{tabular}{|c|c|c|c|c|c|c|}
\hline $\begin{array}{c}\text { Katılımcı } \\
\text { Kodu }\end{array}$ & Cinsiyet & Yaş & Eğitim & $\begin{array}{c}\text { Medeni } \\
\text { Durum } \\
\end{array}$ & Geldiği yer & \begin{tabular}{|c} 
Geldiği \\
$Y_{11}$
\end{tabular} \\
\hline K1 & Erkek & 26 & Lise & Bekâr & Deyr Ez Zor & 2016 \\
\hline K2 & Kadın & 28 & Üniversite & Evli & Şam & 2013 \\
\hline K3 & Kadin & 29 & Ortaokul & Bekâr & Halep & 2014 \\
\hline K4 & Kadin & 44 & İlkokul & Bekâr & Halep & 2014 \\
\hline K5 & Erkek & 36 & Ortaokul & Evli & Halep & 2013 \\
\hline K6 & Kadın & 36 & İlkokul & Evli & Halep & 2014 \\
\hline K7 & Erkek & 30 & Lise & Evli & Deraa & 2018 \\
\hline K8 & Kadin & 33 & Lise & Evli & Şam & 2016 \\
\hline K9 & Erkek & 70 & İlkokul & Evli & Halep & 2013 \\
\hline K10 & Erkek & 34 & Ortaokul & Evli & Halep & 2013 \\
\hline K11 & Kadın & 32 & Ortaokul & Evli & Halep & 2017 \\
\hline K12 & Kadin & 20 & Lise & Evli & Halep & 2012 \\
\hline K13 & Kadin & 24 & Ortaokul & Evli & İdlip & 2014 \\
\hline K14 & Kadın & 35 & Okuma-yazma bilmiyor & Evli & Halep & 2015 \\
\hline K15 & Erkek & 42 & Ortaokul & Evli & Halep & 2014 \\
\hline K16 & Kadin & 31 & Ortaokul & Evli & Halep & 2014 \\
\hline K17 & Kadin & 66 & İlkokul & Dul & Halep & 2014 \\
\hline K18 & Kadın & 32 & Lise & Evli & Halep & 2013 \\
\hline K19 & Kadin & 27 & Lise & Evli & Halep & 2014 \\
\hline K20 & Erkek & 27 & Ortaokul & Evli & Humus & 2016 \\
\hline K21 & Erkek & 38 & Ortaokul & Evli & Şam & 2014 \\
\hline K22 & Erkek & 27 & Ortaokul & Evli & Halep & 2013 \\
\hline K23 & Kadin & 30 & Lise & Evli & Halep & 2012 \\
\hline $\mathrm{K} 24$ & Kadin & 46 & İlkokul & Dul & Halep & 2015 \\
\hline K25 & Erkek & 32 & Ortaokul & Evli & Halep & 2014 \\
\hline $\mathrm{K} 26$ & Erkek & 57 & İlkokul & Evli & Şam & 2015 \\
\hline K27 & Kadin & 27 & Ortaokul & Evli & Halep & 2013 \\
\hline K28 & Kadın & 34 & Ortaokul & Evli & Halep & 2017 \\
\hline K29 & Kadin & 30 & Lise & Evli & Şam & 2014 \\
\hline K30 & Erkek & 19 & Lise & Bekâr & İdlip & 2015 \\
\hline
\end{tabular}




\section{Suriyelilerin Misafirlik Algısı}

Çalışmanın saha araştırması kısmında görüşülen katılımcılara "Türkiye' de misafir olduğunuzu düşünüyor musunuz? ve "Misafir denilmesi hoşunuza gidiyor mu?" soruları yöneltilmiştir. Suriyeliler ile birlikte gündeme oturan misafirlik kavramı ülkede uzun süre konuşulan bir konu olmuştur. Suriyelilerin ise "misafir" kavramına dair düşünceleri "onların bakış açısıyla" Türkiye'deki konumlarını belirlemek adına ortaya konmaya çalışılmıştır. Katılımcıların yarısı (15 kişi) Türkiye' de misafir olduğunu düşünmektedir.

Misafiriz tabi. Hem misafir denmesi bir yönden iyidir. Çünkü bana bir gün ülkeme döneceğim umudunu veriyor (K3; Kadın, 29, Halep, 2014).

Evet, burada misafiriz zaten savaş bitene kadar buradayız. Misafir denmesi beni rahatsiz etmez (K13; Kadın, 24, İdlip, 2014).

Misafir denmesi beni rahatsız etmiyor. Misafiriz zaten, savaş bitsin geri döneceğiz (K14; Kadın, 35, Halep, 2015)

Biz zaten belli bir zamana kadar buradayı, biz misafiriz (K15; Erkek, 42, Halep, 2014).

Görüşülen kişilerin bir kısmı (11 kişi) Türkiye'de misafir olmad1ğını düşünmektedir. Ayrıca bu kişiler arasında (4 kişi) misafir denilmesinden hoşlanmadığını belirtenlerde bulunmaktadır.

Misafir dedikleri zaman üzülüyorum ve ağlıyorum. Şuan Suriye'de ki bazı yerlerde savaşlar bitti ya bu yüzden bize "savaş bitti hadi gidin artık" diyorlar. Buna çok kırllıyorum. Oradaki evimi ve işimizi kaybettik. Ama eşim artık burada çalışıyor ve burada yaşıyoruz (K16; Kadın, 31, Halep, 2014).

Misafir denilmesi benim hoşuma gitmiyor. Vatandaşlık alıp burada kalmak istiyorum (K17; Kadın, 66, Halep, 2014).

Burada hizmet alırken mesela hastanelerde, eczanelerde falan misafir olduğumu hissetmiyorum. Ama bazı insanlar sana misafir olduğunu hissettiriyor (K4; Kadın, 44, Halep, 2014).

Başka bir ülkeye gitmek istemiyorum, çocuklarda alıştı. Burada misafir değil kahıcıyız artık (K8; Kadın, 33, Şam, 2016). 
Görüşülen kişilerden 2'si ise Türkiye' deki konumlarının devlet ve toplum tarafından belirleneceğini ifade etmiştir.

Onu Allah bilir, misafir derlerse misafiriz değilsiniz derlerse de misafir değiliz onlara kalmış (K5; Erkek, 36, Halep, 2013).

Yani şöyle biz buraya sonradan geldik. Misafir deseler misafiriz, mülteci deseler mülteciyiz. O yüzden bir şey diyemem (K18; Kadın, 32, Halep, 2013).

Görüşülen kişilerin 15'i misafir olduğunu, 11'i ise misafir olmad1ğını düşünmektedir. Görüşülen 2 kişi ise misafirlik durumlarının geldikleri yer tarafından belirlendiğini diğer 2 kişi ise misafirlikle ilgili bir fikri olmadığını belirtmiştir.

\section{Suriyelilerin Gelecek Beklentisi Ve Aidiyet Durumları (Geçici- lik/Kalıcılık)}

Geçici koruma kapsamında olan Suriyelilerin gelecek beklentilerini ortaya koyabilmek ve aidiyet durumlarını öğrenebilmek adına görüşülen kişilere "Geleceğiniz hakkında ne düşünüyorsunuz?" ve "Türkiye'de geçici olarak mı yoksa kalıcı olarak mı yaşadığınızı düşünüyorsunuz?" soruları birlikte yöneltilmiştir. Görüşülen kişilerin yarısından fazlası (19 kişi) Suriye'de belli bir müddet daha suların durulmayacağı, şu anki durumda Türkiye' de yaşamaya devam edecekleri ve savaş biterse geri dönecekleri yönünde cevaplar vermiştir. Ayrıca bu kişilerden bir kısmı (7 kişi) bu süreç içerisinde Türkiye' den başka ülkeye gitmek istemediklerini de belirtmişlerdir.

Hayır, Türkiye'de kalıc değiliz. İnşallah döneceğiz, savaşın bitmesini bekliyoruz (K1;Erkek, 26, Deyr Ez Zor, 2016)

Şuan çatışmalar devam ettiği için kalıcı gibiyiz. Türkiye'den başka bir ülkeye gitmek istemem. Ama Suriye'de savaş biterse döneceğiz. Ailemiz evimiz her şeyimiz orada (K2; Kadın, 28, Şam, 2013).

Şimdilik buradayız. Ama Suriye'de savaş biterse hemen döneceğiz. Ama savaş bitmezse de Türkiye'den başka bir ülkeye kesinlikle gitmek istemem (K3; Kadın, 29, Halep, 2014). 
Şimdilik buradayız. Savaş biterse ülkeme dönmek isterim. Ama buradan başka bir ülkeye gitmek istemem. Burada rahatız ve burası bir İslam ülkesi (K4; Kadın, 44, Halep, 2014).

Onu Allah bilir. Ama buradayız başka bir yere gitmeyiz. Savaş biterse Suriye'ye döneriz. Çünkü burada kira verince maaşımız yetmiyor ama orada kendi evimiz var (K5; Erkek, 36, Halep, 2013).

Bence biz şimdilik buradayız, Suriye şuan dönülecek gibi değil (K6; Kadin, 36, Halep, 2014).

İş piyasasına erişim sığınmacılar için toplumla bütünleşmenin en temel dinamiği olarak görülmektedir. Bu anlamda iş sahibi olabilmek, kendi hayatını idame ettirebilmek için birçok açıdan entegrasyonu kolaylaştırıcı bir işleve sahiptir (Üstün, 2016:1). Buradan hareketle bir katılımcı iş piyasasına erişemediğinden ötürü bu durumun yol açtığı sorunları şu şekilde ifade etmiştir:

Buradan her an gidebilirim. Çünkü çalışmak istiyorum ama burada iş bulamadım, Türkçe bilmiyorum, henüz kimliğim bile yok. Elim kolum bağhl o yüzden başka bir yere gidebilirim (K7; Erkek, 30, Deraa, 2018).

Görüşülen kişilerin bir kısmı (11 kişi) Türkiye'de kalıcı olduklarını ifade etmiştir. Bu kişilerden 3'ü bu süreç içerisinde Türkiye'den başka bir ülkeye gitmek istemediğini ayrıca olarak belirtmiştir.

Başka bir ülkeye gitmek istemiyorum, çocuklarda alıştı. Burada kalıcıyız $\operatorname{art\imath k}$ (K8;Kadın, 33, Şam, 2016).

Kalıcıyız bence artık. Ailemdeki büyükler burada işe girdi çalışıyor, ben okula gidiyorum. Suriye dönülecek gibi değil şu an. Savaş bitmiyor bitse bile artık Suriye yerle bir oldu. O yüzden biz burada yaşayacă̆ız (K30; Erkek, 19, İdlip, 2015).

Suriye'ye dönme ümidi azalan bir katılımcı Türkçe olarak kesin bir ifadeyle kalıcı olduğunu belirtmiştir:

Vallahi ben kalmak istiyorum, burada kalıcıyım. Artık burada çalışıyorum ve ailemle burada yaşıyoruz. Suriye bitti. Evimiz yıkıldı, okullar yakıldı ben oraya niye bir daha döneyim ki (K10; Erkek, 34, Halep, 2013). 
Katılımcılardan 2'si ise Türk biri ile evlendiğini söyleyerek Türkiye'de kalıcı olduklarını beyan etmişlerdir.

Ben artık burada evlendim ve eşim Türk. O yüzden burada kalıcıyım (K11; Kadın, 32, Halep, 2017).

Benim kocam Türk. Artık Suriye'ye geri dönmem. Burada kahııyım. Ama arada Suriye'ye ziyarete gidebilirim o kadar (K12; Kadın, 20, 2012, Halep).

Genel anlamda verilen cevaplar düşünüldüğünde Suriyelilerin yarısından fazlasının (19 kişi) mevcut şartlardan dolayı gelecekleri hakkında bir belirsizlik hissettikleri ortadadır. Suriye şartlarında herhangi bir iyileşmesinin olmaması onları büyük bir belirsizliğin içerisine sürüklemektedir. Geçici olarak burada yaşadıkları ve savaşın bitmesi halinde geri dönecekleri düşüncesine gerçekçi bir yaklaşımla bakılacak olursa mevcut durumun pekte iç açıcı olmadığı görülmektedir. Çünkü Suriye' deki savaşın ne zaman biteceği henüz ön görülememektedir. Bununla birlikte Türkiye'de kalıcı olarak yaşadığını düşünenlerin vatandaşlığa alınmaması durumunda geçici koruma altında temel haklara erişme sorunları yaşaması muhtemel görünmektedir.

\section{Suriyelilerin Vatandaşlık Algısı}

Suriye' de 8 yıldır süren savaşın bitmemesi, ülkedeki pek çok şehrin artık yaşanılmaz hale gelmesi Suriyelilerin ülkesine dönmesini giderek güçleştirmektedir. Vatanlarına dönme ümidi taşımasına rağmen dönemeyen, geldikleri ülkede kendine bir yer bulmak isteyen bu millet aksi takdirde vatansız kalmak gibi bir durumla karşılaşacaktır. Zamanla gelişen şartlar (yeni doğan bebekler, eğitim gören çocuklar) özellikle Suriyeli ailelerin çocuklarının Türkiye'ye aidiyet kazanmalarının önünü açmaktadır. Bu kanı araştırmaya katılan ailelerin ifadelerinde de açıkça ortaya konulmuştur. Katılımcılara "Vatandaşlık verilmesini istiyor musunuz? Neden?" sorusu yöneltilmiştir. Görüşülen kişilerin büyük bir kısmı (25 kişi) vatandaşlık almak istediğini beyan etmiştir. Verilen cevaplara göre, Suriyeliler tarafından vatandaşlık "hak" ve "güven" kaynağ1 olarak görülmektedir. Vatandaşlık almaya yönelik gösterilen önemli gerekçelerden biri de ailelerin "çocuklarının geleceği ve güvenliği" için iyi olacağı kanaatidir. 
Vatandaşlık verilmesini isterim tabi. En azından artık Türkiye'de kalıcı olduğumu daha çabuk kabullenirim (K19; Kadın, 27, Halep, 2014).

Evet, vatandaşlık isterim. Vatandaşlık alırsam daha güvende hissederim kendimi. Doktor ve ilaç imkânlarmdan daha iyi yararlanabilirim (K20; Erkek, 27, Humus, 2016).

Verilse çok memnun olurum. Mesela biz ülke içinde bir yere gitmek istesek bile emniyetten izin almamız gerekiyor. Ama vatandaşlik verilse daha özgür olurum, istediğim yere rahatça gidebilirim (K10; Erkek, 34, Halep, 2013).

Vatandaşlık çıkarsa niye istemeyeyim herkes ister. Çocuklarım için çok iyi olurdu hakların alırlardı (K2; Kadın, 28, Şam, 2013).

Artık Suriye'ye dönemeyecek gibiyiz. O yüzden çocukların geleceği ve güvenliği için vatandaşlık verilmesini isterim (K21; Erkek, 38, Şam, 2014).

Evet, isterim. Bizim için, çocuklarımız için daha iyi ve güvenli olurdu (K6; Kadın, 36, Halep, 2014).

Verseler alırız. Çünkü bir güvence altında olmuş oluruz ve daha sağlam dururuz (K22; Erkek, 27, Halep, 2013).

Vatandaşlik tabii isteriz. En azından kendimizi güvende hissederiz (K23; Kadın, 30, Halep, 2012).

Vatandaşlık almak istediğini söyleyen bazı katılımcılar (4) Türkiye'ye alıştıklarını söyleyerek isteklerini gerekçelendirmiştir.

Burayı sevdik ve alıştık o yüzden vatandaşlık isterim (K3; Kadın, 29, Halep, 2014).

Evet, buraya alıştım, vatandaşlık almak istiyorum. Çünkü kendimi güvence altında hissederim (K24; Kadın, 46, Halep, 2015).

Vatandaşlık isterim çünkü burayı sevdik ve alıştık. Kalıcı olabilmek için bir güvence olur (K4; Kadın, 44, Halep, 2014).

Görüşülen kişilerden 2'si ise mevcut durumun belirsizliğine vurgu yaparak şartlar dâhilinde vatandaşlık almak istediklerini belirtmişlerdir.

Burada kalıcıysak vatandaşlık isterim ama geçiciysek vatandaşlı̆̆a gerek yok (K25;Erkek, 32, Halep, 2014). 
Artık Suriye'ye dönemezsek çocukların geleceği ve güvenliği için vatandaşlık verilmesini isterim (K21; Erkek, 38, Şam, 2014).

Suriye' de savaşın biteceğine kesin olarak bakan katılımcllar (3 kişi) ise vatandaşlık almak istemediklerini ifade etmişlerdir. Vatandaşlık istemediğini belirten kişilerin sebepleri farklılık göstermektedir. Suriye'ye döneceğini düşünen kişiler kesin bir şekilde vatandaşlık almak istemediklerini ifade etmişlerdir. Bir başka katılımcı ise vatandaşlık almanın bazı sorumluluklar getireceğini öne sürerek vatandaşlık almak istemediğini belirtmiştir.

Bir gün elbet Suriye'de savaş bitecek ve bizde geri döneceğiz. O yüzden vatandaşlık almaya gerek yok (K13;Kadın, 24, İdlip, 2014).

Hayır, ben istemiyorum. Çünkü sonunda yine ülkeme döneceğim. $O$ yüzden vatandaşlığa gerek yok (K1; Erkek, 26, Deyr Ez Zor, 2016).

Ben şimdi paramı ancak yetiştiriyorum. Vatandaş olunca bazı yerlere para ödemek zorunda kalacağım. Hastanelere ve ilaçlara para vermek zorunda kalacağım. Ama biz şuan ücretsiz faydalanıyoruz (K5; Erkek, 36, 2013, Halep).

Verilen cevaplar doğrultusunda görüşülen kişilerin büyük bir kısmının (25) vatandaşlık alma eğiliminde olduğu görülmektedir. Buna karşılık görüşülen kişilerin yarısından fazlası (19 kişi) aynı zamanda Türkiye' de geçici olarak yaşadığını ifade etmiş̧tir. Bakıldığında bu kişilerin hem Türkiye' de geçici olarak yaşadığını hem de vatandaşlık almak istediğini belirtmesi çelişkili bir yaklaşım tarzı olarak ortaya çıkmaktadır. Bu durum, Suriyelilerin bir tarafta Türkiye'ye alışma ve burada bir düzen kurmanın verdiği rahatlık, diğer tarafta ise vatanına olan aidiyetinin ve akrabalık ilişkilerinin zamanla kaybolma korkusundan ileri geldiği düşünülebilir. Evli ve çocukları olan ailelerin özellikle çocuklarını gerekçe göstererek güvence altında yaşamaları için vatandaşlık almak istedikleri görülmektedir. Suriyeliler açısından bakıldığında vatandaşlık, "hak" ve "güven" kaynağı olarak görüldügünden bu konuda taleplerinin olması kaçınılmazdır. "Suriyelilere vatandaşlık" mevzusuna Türkiye açısından bakıldığında ise geçici koruma kapsamında olan kişilerin geleceğinin belirsizliği, toplumda var olma isteği, sayının çokluğu, toplumun tepkisi ve ülkenin ekonomik, 
sosyolojik ve siyasi durumu bir bütün içinde ele alınarak çözümlenmelidir.

Zira Suriyelilerin ülkelerine geri dönmesi gerçekleşmezse 4 milyona yakın insanın geleceğinin ne olacağına dair pek çok soru ve sorun ortaya çıkacaktır. Adından da anlaşılacağı üzere geçici koruma hakkı bir süreliğine verilmiştir. Bu kadar insanın geçici koruma kimlik kartıyla ne kadar süre Türkiye'de barınabileceği belirsizliğini korumaktadır (Erdem, 2017:348). Tüm bunlara karşın Türk toplumunun Suriyelilere vatandaşlık verilmesine dair vereceği tepki de önemlidir. M. Murat Erdoğan'ın 2014 yılında gerçekleştirdiği bir saha araştırmasında Türk halkına "Sığınmacılar Türkiye vatandaşlığına alınmalıdır" önermesi sunulmuştur. Araştırma sonucunda Türk vatandaşlarının bu önermeye açık bir biçimde karşı çıktığı belirlenmiştir (Erdoğan, 2018a:146). Yine Erdoğan'ın Suriyeliler Barometresi isimli çalışmasının saha araştırması kısmında Türk vatandaşlarına Suriyelilere vatandaşlık verilmesiyle ilgili görüşleri sorulmuştur. Araştırma sonucunda katılımcıların yaklaşık \% 80'inin Türkiye'ye gelen bütün Suriyelilerin Türk vatandaşlığı almasına karşı olduğu saptanmıştır (Erdoğan, 2018b:83). Bu araştırma sonuçlarına göre Türk halkının Suriyelilere vatandaşlık verilmemesi gerektiğine dair kesin bir tavrı bulunduğunu söylemek mümkündür. Hükümet tarafında ise yetkililerin hali hazırda çalışmalarının olduğu, birtakım şartların getirilmesi doğrultusunda Suriyelilerin vatandaşlık alabilmesinin mümkün olabileceği açıklamaları yapılmıştır.

Şimdiye kadar vatandaşlık alan Suriyelilerin olduğu düşünüldügünde zamanla yaygınlık kazanması beklenen bir durum olarak görülmektedir. Genel çerçeveye bakıldığında ise "Suriyelilere vatandaşlık" konusunun üç ayrı aktörü bulunduğunu söylemek gerekmektedir. Birinci aktör Türkiye Cumhuriyeti Devleti'dir. İkinci ve üçüncü aktör ise Suriye halkı ve Türkiye halkıdır. Bütün bu şartlar düşünüldüğünde yoğun bir mesai harcanması ve farklı etkenlerin bütün bir çerçevede değerlendirilmesi bu sürecin yönetilmesi açısından büyük önem taşımaktadır. 


\section{Sonuç ve Değerlendirme}

Suriye' deki şiddetten ve zulümden kaçan milyonlarca insan Türkiye sınırından içeri girmiştir. Bunun üzerine Türkiye açık kapı politikası ilan ederek Suriyelilerin ülkeye girişine müsaade etmiştir. 2014 yılında devlet tarafından Geçici Koruma Yönetmeliği yürürlüğe koyulmuş ve Suriyelilere geçici koruma kimlik kartı verilmiştir. 2011 yılından beri giderek artan Suriyeli sayısı 2019'da 3,5 milyonu geçmiştir.

Suriye' deki çatışmaların devam etmesi gelen Suriyeli sayısını artırmakta, ülkesine geri dönmek isteyen kişilerinse ümidini azaltmaktadır. Bu süreçte Suriyelilerin Türkiye'deki geleceği misafirlik tartışmaları üzerinde yükselirken bu durum farklı sorunları beraberinde getirmektedir. Göç sürecinin başlarında misafir ve geçici olarak kalacakları düşünülen Suriyelilerin zaman geçtikçe Türkiye'ye alışması, bir düzen kurması ve topluma uyum sağlaması ülkelerine dönme eğilimini azaltmaktadır. Bu süreçten sonra savaş bitse bile hatırı sayılır bir kesimin Türkiye' de yaşamaya devam edeceği ön görülmektedir. Pek çok çalışmada geçici koruma kapsamına alınan Suriyelilerin zamanla Türkiye'de kalıcı olacağına dair öngörülerde bulunulmuştur (Erdoğan, 2018a; Orhan ve Şenyücel, 2015; Kutlu, 2015).

Tüm bunların sonucunda Suriyelilerin vatandaşlık alma konusundaki eğilimleri giderek artmaktadır. Geçici kimlik statüsünün sınırlı olanaklar sunması ve belirli bir süreliğine verilmesi Suriyelilerin geleceği için kaygı verici olarak görülmektedir. Kitlesel göç akımının başladığı ilk günden bu yana Türkiye'nin insani anlamda üzerine düşen her şeyi yapmış olmasına rağmen Suriyeli sayısının fazla olması ve göçün akınlar halinde gerçekleşmesi büyük sorunları da beraberinde getirmiştir. Bu anlamda Suriyelilere vatandaşlık verilmesi de Türkiye için başlı başına üzerinde tartışılan bir konu olmuştur.

Suriye'de savaşın bitmemesi ve çatışmaların halen sürüyor olması geçen 8 yıllık göç sürecinde Suriyelilerin toplumdaki yerini belirlemek ve hak talep edebilmek adına onları vatandaşlık istemeye teşvik etmektedir. Özellikle de ailelerin Türkiye'ye uyum 
sağladıklarını söyleyerek çocuklarının daha iyi bir hayat sürmesi açısından vatandaşlık almak istemesi topluma entegre olmaları açısından önemli bir gelişme olarak görülebilir. Suriyelilerin vatandaşlık almak için sunduğu gerekçelerin başında "hak" ve güven" arayışı öne çıkmaktadır. Suriyelilerin vatandaşlık alabilmesi diğer yabancılara getirilen birtakım şartlar ile gerçekleşebilir. Fakat Geçici Koruma Yönetmeliği'ne göre Suriyelilere vatandaşlık verilmesinin önü kapanmıştır. Bu nedenle öncelikle geçici koruma statüsünden çıkmaları ve ya yeni bir düzenlemenin getirilmesi gerekmektedir. Hükümet yetkilileri zaman zaman belirli kriterler gözetilerek Suriyelilerin vatandaşlık alabileceğine dair açılamalar yapsa da geçici koruma altında olan Suriyeliler özelinde vatandaşlık verilme ile ilgili herhangi yeni bir düzenleme bulunmamaktadır. Türkiye'de geçici koruma kapsamına alınan Suriyelilerin geleceği hakkındaki belirsizliğin giderilmesi ise ancak ülkelerindeki savaşın bitmesi halinde geri dönmeleri ya da Türkiye'de vatandaşlık almalarıyla mümkün olabilir. Aksi takdirde vatansız kalmak ve ne zaman biteceği belli olmayan bir gelecek kaygısı ile yaşamak zorunda kalacaklardır. 


\section{Kaynakça}

Erdem, B. (2017). Geçici Koruma Statüsündeki Suriyelilerin Sosyal, Siyasi ve Vatandaşlık Hukuku Bakımından Türkiye'deki Durumları. Public and Private International Law Bulletin, 37(2), 332-351.

Erdoğan, M. M. (2018a). Türkiye'deki Suriyeliler (2. b.). İstanbul: İstanbul Bilgi Üniversitesi Yayınları.

Erdoğan, M. M. (2018b). Suriyeliler Barometresi; Suriyelilerle Uyum İçinde Yaşamın Çerçevesi (1. b.). İstanbul: İstanbul Bilgi Üniversitesi Yayınları.

Geçici Koruma Yönetmeliği. (2017, 01 06). 01 06, 2019 tarihinde İçişleri Bakanlığ 1 Göç İdaresi Genel Müdürlüğü: http: / / www.goc. gov.tr/icerik3/gecici-koruma-yonetmeligi_409_558_4622 adresinden alınd 1

Gülyaşar, M. (2017). Suriyeliler ve Vatandaşlık: Yerel Halk ve Suriyeli Sı̆̆ınmacılar Çerçevesinde Bir Değerlendirme. Uluslararası Toplum Araştırmaları Dergisi, 7(13), 680-705.

Güney, Ü., \& Konak, N. (2016). Bolu'da Suriyeli ve Iraklı Sığınmacılar Vatandaşlık ve Kaynak Dağılımı Temelinde Öteki Alg1s1. Marmara Üniversitesi Sosyal Bilimler Dergisi, 4(2), 113-133.

Kap, D. (2014). Suriyeli Mülteciler: Türkiye'nin Müstakbel Vatandaşları . Akademik Perspektif, 30-35.

Kutlu, Z. (2015). Bekleme Odasından Oturma Odasına: Suriyeli Mültecilere Yönelik Çalışma Yürüten STK'lara Dair Kısa Bir Değerlendirme. Mart 23, 2019 tarihinde https://www.academia.edu: https://www.academia.edu/13240560/_2015_ Bekleme_Odasından_Oturma_Odasına_Suriyeli_Mültecilere_Yönelik_Çalışma_Yürüten_STKlara_Dair_Kısa_Bir_Değerlendirme adresinden alınd 1

Mültecilerin Hukuki Durumuna İlişkin Sözleşme. (2015, 03 12). 01 06, 2019 tarihinde İçişleri Bakanlığı Göç İdaresi Genel Müdürlügü: http:/ / www.goc.gov.tr/icerik3/multecilerin-hukukidurumuna-iliskin-sozlesme_340_341_641 adresinden alındı

Orhan, O., \& Gündoğar, S. S. (2015). Suriyeli Sı̆̆ınmacıların Türkiye'ye Etkileri. Ankara: ORSAM-TESEV Raporu. Mart 
24, 2019 tarihinde http://tesev.org.tr/wp-content/uploads/2015/11/Suriyeli_Siginmacilarin_Turkiyeye_Etkileri. pdf adresinden alındı

TBMM Araştırma Merkezi. (2011). Ülke Anayasalarında Vatandaşlık Tanımları-TBMM. Ankara: Türkiye Büyük Millet Meclisi Araştırma Merkezi. 02 20, 2019 tarihinde anayasa.tbmm. gov.tr: https: / / anayasa.tbmm.gov.tr/docs / vatandaslik_tanimlari.pdf adresinden alınd 1

Turner, B. (1993). Contemporary Problems in the Theory of Citizenship. London : Sage Publications.

Türkiye Cumhuriyeti Anayasası. (tarih yok). 01 20, 2019 tarihinde Turkiye Buyuk Millet Meclisi Baskanligi [TR]: https: / / www. tbmm.gov.tr/anayasa/anayasa_2018.pdf adresinden alındı

Uluslararası Göç Örgütü. (2009). Göç Terimleri Sözlüğü. (B. Çiçekli, Dü.) İsviçre: Uluslararası Göç Örgütü. 01 06, 2019 tarihinde www.goc.gov.tr: www.goc.gov.tr/files / files / goc_terimleri_sozlugu.pdf adresinden alınd 1

Üstün, N. (2016). Suriyelilerin Türk İşgücü Piyasasına Entegrasyonu Sorunlar-Öneriler. Konya: Konya Ticaret Odası / Ekonomik Araştırmalar ve Proje Müdürlüğü.

www.habertürk.com. (2019, 01 08). İçişleri Bakanı Süleyman Soylu: Türkiyesdeki Suriyelilerin çoğu Misak-ı Milli sınırları içinden. 02 15, 2019 tarihinde www.habertürk.com: https://www. haberturk.com/icisleri-bakani-suleyman-soylu-turkiyedekisuriyelilerin-cogu-misak-i-milli-sinirlari-icinden-2283766 adresinden alınd 1

Yalçın, C. (2004). Göç Sosyolojisi. Ankara: Anı Yayıncılık. 